\title{
Indonesian Crafts: The Overlooked Potential of Geographical Indication
}

\author{
Fadilah H. Arief
}

\begin{abstract}
Geographical Indication (GI) is created to protect a product based on its geographical location that is prone to free-riding, and also to protect the culture and the customer. Indonesia has regulated GI since 1997, but the number of the registered craft products did not increase significantly until 2015. By examining the regulations from the cultural ownership perspective, this study founds the Indonesian crafts' potentials behind the implementation of GI regulation, which needs the collaboration from various actors to solve the challenges.
\end{abstract}

Index Terms-Collaboration, crafts, culture, geographical indication, intellectual property.

\section{INTRODUCTION}

Indonesia, the fourth most populated country in the world, with highly diverse natural resources, ethnicities, languages, and cultures. The country's slogan, "unity in diversity" shows that Indonesia is united and made of different cultural backgrounds [1].

Despite owning a high number of cultural assets, Indonesia is still struggling to develop and utilize those resources as a cultural and creative economy. The creative economy sector is controlled under Badan Ekonomi Kreatif (Bekraf) or Creative Economy Agency. They focus on developing 16 different sub-sectors to increase the GDP double fold the current percentage, 7 percent [2]. Craft, as one of the sub-sectors, is also expected to contribute in order to reach the target for next year.

One of the concerns in introducing the innovation for Indonesia's creative industry sector is intellectual property rights (IPR). The government regulates five types of IPR: patent, trade mark, industrial design, copyright, and geographical indication (GI). For the craft industries, in which many stem from traditional culture and know-how, GI is the most suitable to protect products legally based on the origin of the product's signs. As the member of the World Trade Organization (WTO), Indonesia should follow the Trade-Related Aspects of Intellectual Property Rights (TRIPs) Agreement to apply the GI regulation [3]. However, until 2015, there was only one craft product registered: Jepara carved furniture. The rest of the registered products were agricultural products, such as coffees and white pepper, and also several foreign GIs, including Champagne and Parmigiano Reggiano [4]. GI, which is supposed to safeguard original products from Indonesia, is not yet fully applied for

Manuscript received June 27, 2016; revised August 1, 2016. This work was supported by Indonesia Endowment Fund for Education.

F. H. Arief is with Creative and Cultural Entrepreneurship programme at Goldsmiths, University of London, UK (e-mail: farie001@gold.ac.uk, fadilah.arief@gmail.com). the craft industries.

Meanwhile, by registering craft products and increasing the geographically-based brand quality, many actors are also expected to be more encouraged working with the artisans and create innovation through collaboration. In the future, for example, fashion designers will be more likely to use Sikka Ikat and Batik Solo for their collections, or even a possibility of the foreign furniture retailers to put Jepara carved furniture in their catalogue.

Based on those issues, this research will critically examine the importance of implementing GI for Indonesian crafts and its benefits for the people as the owner of the cultures and the actors of collaboration: to protect the craftsmen and customers, to promote Indonesian craft products in wider market, to develop rural area and to increase collaboration. The qualitative method is implemented in this study, by analyzing the related regulations which were being implemented by the end of 2015 . Two study cases will be highlighted in this research, i.e. Jepara carving furniture and Sikka Ikat.

The introduction contains the background of the essay, continued with the definition of the key terms. The third part will explore the issue of the culture ownership. The fourth part is about GI regulation in Indonesia, including the historical background and the future regulation development. The fifth part is the importance of GI, especially in terms of fostering collaboration, and also will include case studies of Jepara carved furniture and Sikka Ikat. The last part will summarise the discussions in this essay and include several suggestions to support the implementation of GI.

\section{DEFINITIONS}

\section{A. Culture}

The term 'culture' was suggested by the Europeans and now can be defined in many possible ways, or simply say that 'culture is everything' [5]. The word 'culture' is originated from Latin, colere, which means cultivate and something that 'have been grown and groomed'. Culture is created and modified through the time and embodied in everyday life and behaviour for a community that share the same space and historical background [6]. Therefore, the definition of culture is constantly changing [7].

Culture is also related to tradition and the combination of 'as roots, destiny, history, continuity and sharing on the one hand, and as impulses, choice, the future, change, and 
variation on the other' [8]. To make it more relevant today, culture has become a property, as Mitchell [5] mentioned Bourdieau, who said that culture is now a commodity based on market. This writing will refers to culture as a combination of tradition and historical background that have been adapted and shared in a community and manifested in the individual and social life, which now has become a commodity.

\section{B. Crafts}

To differentiate it from art and design, crafts should have three characteristics. A craft object should be functional [9] [10], made entirely by hands or partly by machines, and involving a 'skillful-labour' [11]. Craft is considered as 'symbolic cultural product' with sharing the meaning between people in the community [12].

From the legal aspect, craft is a part of tangible Traditional Culture Expression (TCE) that is protected under IPR. This right is valuable to preserve the cultural value behind it, and to protect craft as a market commodity [13].

To sum up, craft is an activity based on traditional and cultural value to create a functional object by craftsmen and artist-craftsmen. The context of craft in this essay will include traditional and contemporary craft, which is still based on TCE.

\section{Geographical Indication (GI)}

The World Intellectual Property Organization (WIPO) from their publication, Geographical Indication: An introduction [14], describes GI as 'a sign used on products that have a specific geographical origin and possess qualities or a reputation that are due to that origin.' The TRIPs agreement, which is also mentioned from the same WIPO publication, explains GI as:

...indications which identify a good as originating in the territory of a Member [of the World Trade Organization], or a region or locality in that territory, where a given quality, reputation or other characteristic of the good is essentially attributable to its geographical origin.

In addition, GI in Indonesia is currently regulated under the Law of Trade Mark. At the time of the writing of this essay, the law concerning GI is being discussed. From the last seminar on 25 November 2015 in Jakarta, the government of Indonesia will revise and launch the new Law of Trade Mark and Geographical Indication [15].

\section{Collaboration}

Many people simply think that collaboration is working with a group of people. But in detail, collaboration is working in a group that generates 'collective knowledge,' resources and skills in a more effective and efficient way to accomplish a better result [16]. They come from 'different values, agendas, institutional support, disciplines, interaction styles'; creating 'cross-cultural,' 'multi-disciplinary' or 'inter-institutional' collaboration; working on the same place, or separated; and associated with the people they already know or even strangers [17]. However, to bridge the misunderstanding from the different cultures and perspectives, communication skills become essential for the collaboration process [18]. Collaboration is not an easy task but if it is successful, it can make a greater impact.

\section{Cultural OWNERShIP}

Culture will always remain in public domain because it belongs to the people [19], but it is inevitable for people to use something in the public domain and turn it into private property [20]. To begin with, a concept about property ownership comes from John Locke, in his book The Second Treatises [21]. He explained that a human owns his body and the works done by his body. When he puts his labour into something from nature or public domain, that item will be his property, as long as the rest from what he claims is enough for others. The ownership is to justify all the rights a person has in regards to the property, including restricting others from using it without any permissions.

On the contrary, Mezey [19] argued that culture does not fit with Locke's property definition because culture does not have amount limitation though someone can claim it to be his property. Culture always belongs to the people, the community, so it is limitless. But when people interact more intensely with their culture, culture could become more valuable. As a result, a clash between two different cultures is also inevitable. Therefore, the presence of cultural law is still important to solve a dispute.

The idea of property is also applied to literature or artistic works. All works are entitled to its author because its authenticity is now related to the existence of the author. Foucault [22] explained that the author function is automatically manifested into the works. This idea defends the ownership of idea expression and the acknowledgment of the author as the rightful owner. This became one of the foundations in establishing copyright systems and other intellectual property (IP) regulations.

The notion of an individual as the owner of a creation was not recognized in the past, when faith-based governments were in power in numerous parts of the world. Many religions, like Christianity, Islam, Hindu, and Buddhism, considered God or the Gods as the real owner of everything, including humans and their ideas [20], [23]. Surprisingly, even in current IP rights, the ideas behind all creations and inventions are not protected because they belong to the public domain [23]. For instance, a book or a writing is protected with copyrights because it is the expression, but the idea of the story is not.

Ideas are originally a private property when they are inside the mind, but once they are publicized, they belong to public domain [20], [23]. Similarly, some inventions today are indebted to previous inventions that inspired the creator [20]. This condition has also happened in case of culture. Those who were involved in the creation of culture are unknown and most probably already dead. All cultural goods can be created because they depend on other earlier actions of inventions too. To illustrate, pottery exists because the late people had created the kiln, and the kiln was created because people had discovered fire.

\section{A. Intellectual Property Rights (IPR) for Culture}

Property rights are required to establish a market [24], thus creating IPR became essential. Moreover, there are many 
disputes regarding culture and IPR between different countries so the world level regulation should be legally set up. This paper will now describe basic principles of IP, including its link with culture/Traditional Cultural Expression (TCE) [23]. Still, there are some points that not suitable for culture (hereafter the terms culture also refers to TCE) or craft.

First, Intellectual Property (IP) is created for a property. Culture is considered as a man-made good, 'groomed' and 'cultivated' in a community [6], which is involved in the process by using human intelligence. Thus, this creative expression could be defined as property because it is the manifestation of what the creators already owned [25].

Second, IP is intangible. All IP comes from ideas, which are intangible. In this case, culture is not only a tangible object, but also intangible object [13], which means untouchable and created as a product of human intelligence, such as folklore and traditional knowledge.

Third, IP only exists when there is a government. The law system is always controlled under the government and related to public policy. Each country has its own set of regulations for IP to define the scope of protection and the punishment for infringement [23]. Yet there are also some cases when one culture exists over the political boundaries, such as the dispute between Indonesia and Malaysia about folksongs and traditional dance [3].

Fourth, IP is implemented through international conventions. In the global market, international agreement is important in creating a single arrangement since the regulations are varied for every country. Currently, there are two main organizations that help maintaining IP and cultural property regulation, World Intellectual Property Organization (WIPO) and WTO. WIPO arranges world meeting and helps its members to set the world level IP agreement. Meanwhile, WTO created a system based on Trade-Related Intellectual Property Rights (TRIPS) agreement and has authority to implement the consequences for its members [23].

Fifth, IP acts as the justification to make 'incentive, reward, disclosure, and human rights.' These reasons may not fit for culture, because they are in public domain and created by unknown authors [19]. At the same time, the people who create cultural goods, like craftsmen, still need protection for their products without claiming full authorship of its culture. The alternatives of IP justification for cultural products will be explained later in detail.

Sixth is property contract. This is to balance rights between the author and public in terms of 'ownership/control' and 'use/access' [23]. Again, this may not be fully relevant for culture that already is in public domain, but it is important to have the property contract to solve national or international disputes. Claim, exploitation and free-riding are parts of this issue.

The last is opting out and all actors having the choice to not use IP rights for their works. The absence of IP may drive innovation faster, like the creation of internet, but failing to protect the product may harm the creator financially as well [23]. For instance, the case of Toraja coffee from Indonesia that was first registered as a trademark in Japan. At the time of its trademark, Indonesia had not yet established the regulation about collective trademark or GI [26].

Concerning the culture, communities have other opinions towards IP. IP system are expected to help communities in economic and social sectors [27]. In addition, legal protections for culture are expected to solve bigger problems in this era of technology, such as: (i) to protect and preserve the heritage of culture, (ii) to promote the artists and 'cultural exchange', (iii) to promote 'cultural diversity', (iv) to respect 'cultural rights', (v) to develop a sustainable economy based on traditional creativity, and (vi) to fulfil the needs of people in the cultural community, for instance counterfeit protection, improper symbol usage and craft style preservation [13].

Consequently, justification of IP, particularly incentive and rewards, are not suitable for culture. The most important reasons to have cultural IP systems are for protection and safeguarding cultural heritage. However, the existing copyright system is more suitable for literature and artwork, such as traditional dance and folksong. In addition, the IP system for culture is not merely focusing on fostering innovation, but its main aims are to protect the existing reputation, distinction and concern for people in the community [13], [28].

For craft, the most appropriate form of rights in the existing IP system is GI [29] for several reasons. Firstly, GI offers collective protection whereas trademark is only for individual items. Also, GI can point out the quality of the cultural product and its relation to the place of origin. It is also more preferable than copyright because protection for people and their culture is not time limited. In short, GI concerns not only the culture sector, but also market and technology development [30], so it can fulfil the communities' needs to save their craft style [13] and sustain them in the commercial market.

\section{B. International Regulations for Geographical Indication}

Regulations to protect GI products was born from a long process, but there are three main agreements. Starting in 1891, the Madrid Agreement defined the term of indication of source'. Then, the Lisbon Agreement of 1958 adopted the definition of 'appellations of origins' [31]. Finally, in 1996, TRIPS combined those definition and mentioned GI in Article 22 as 'indications which identify a good as originating in the territory... or a region or locality... where a given quality, reputation or other characteristics of the good is essentially attributable to its geographical origin' [32]. The definition of territory can be a region or even a country [33].

The Madrid and Lisbon Agreements were not widely popular and only signed by a small number of countries. In comparison, TRIPS was signed by many countries, including Indonesia, and set the standard for its members to create their own special regulation of GI. These countries are allowed to strengthen their domestic IPR regulation, but they are not allowed to weaken it less than what TRIPS had arranged [3]. Therefore, TRIPS has become a pioneer in establishing the world IPR system which should be obeyed by its members [34].

Implementing GI can create impact towards the balance of export-import trading. Developing countries are trying to lower the protection to induce its market, whilst developed countries are trying to build extra protection [27]. The current 
discussion about GI protection in TRIPS is the extension of protection for all products, not only for wine and spirit. At the same time, the debate around the effectiveness of GI for cultural products are still going around, especially between the 'old world' and 'new world', or developed and developing countries respectively [31], [35]. Developing countries, including Indonesia, are benefitting for the implementation of GI [36], but they are prone to free-riding and genericizing for their registered GI products. The 'old worlds' are against this for reasons including costing time and money [34], [37]. Parry [38] also says that the geographical factor is no longer relevant, and the human factor should not be separated in the creation process.

The current GI system is not enough to protect cultural products, especially for developing countries, including Indonesia [12], [34]. The extension of GI can be an opportunity to gain bigger protection in the global market. Consequentially, people in cultural communities will also receive better benefits to safeguard their culture and its craft.

\section{GI REGULATION FOR CRAFTS IN INDONESIA}

\section{A. Current GI Regulation}

In Indonesia, people can register their products for GI after the authorization of Government Regulation (hereinafter GR) Number 51/2007 in September 2007. This regulation was created to implement the Trade Mark (hereinafter TM) Law Number 15/2001 from Article 56, therefore this regulation has lower legal status than TM Law 15/2001. Two years after the TRIPS agreement had been recognized, the government of Indonesia created a simple regulation about GI and Indication of Source in TM Law 14/1997. There were three articles about GI, and then after amended into TM Law $15 / 2001$, the contents are still the same. Then, GR 51/2007 was made to enforce GI based on TM Law 15/2001 [3]. At the time of the writing of this essay, the new law concerning GI is being discussed. From the last seminar on 25 November 2015 in Jakarta, the government of Indonesia will revise and launch the new Law of Trade Mark and GI [15].

From TM Law 15/2001 in Article 56, GI is described as 'a sign which indicates the place of origin of goods, which due to its geographical environment factors, including the factor of the nature, the people or the combination of the two factors, gives a specific characteristics and quality on the goods produced therein'. That definition is more similar to the Appellation of Origin in the Lisbon Agreement, because the place name should be used and the geographical environment is important. GI in TRIPS definition does not only need geographical environment, but the reputation, quality, and other characteristics are more important. In addition, TRIPS allows use of another name that 'indirectly' statesits original location. These could create confusion because Indonesia is a member of TRIPS, not part of the Lisbon Agreement, but using the definition from the Appellation of Origin [3].

In order to register a product for GI, the applicant should fill the application files and create the Book of Requirement (Code of Practice). That book will have detailed information of the product, such as the special characteristics, quality, 'history and tradition', and labelling. That will be a guide when a producer wants to have the GI sign for his product [39]. Since the registration process will take time and need experts to fulfil the requirements, it should be considered that this may be difficult and might hinder the plan to increase national GI products [3], [40].

\section{B. GI for Craft Products}

Based on TM Law 15/2001, 'handicraft' or craft are eligible for GI, and people who produce the craft, or the craftsmen, are able to apply for registration. However, from Article 56, the geographical environment becomes compulsory to make a craft product qualified for GI. Those requirements are more suitable for agricultural goods, which carry a combination of human and natural factor that influence the quality, and the 'geographical environment' [3]. This is also one of the factors that makes the registration process difficult for applicants. Until March 2015, there was only one craft product that successfully has been registered out of 31 other agricultural products: Jepara carving furniture. Overall, there has been no growth in numbers for craft since April 2010 [4].

Meanwhile, other countries paid more attention to their GI potential craft products. For example, India has 128 registered GI craft out of 200 items since 2003-2015 [41], Turkey had 39 craft out of 129 items between 1996-2010 [42], and Thailand had 38 local products from 2004-2013, and three of their GI craft were selected on WIPO Branding Project [43]. In further comparison with other ASEAN countries, such as Singapore, Thailand, and Malaysia, their GI regulations do not use the whole combination of geographical environment, natural and human factor altogether, but one of them can be an alternative [3]. This would make it easier to apply for GI in those countries. Surprisingly, the protection for GI product in Singapore is automatic, like copyright system, without any registration [44].

Although many countries has used GI for their products, the benefits of GI in developing countries are being questioned. Some people argue about the ineffectiveness of cultural benefits, because the government can be more concerned about the state project and no longer care about local and traditional values [45], [46]. On the economic aspect, GI is a new concept for the developing world [35] and the cost for marketing and campaigning can exceed the financial benefits from trade [45]. Without the TRIPS extension of GI law for craft (and other products other than wine and spirit), it would be difficult to prevent free-riders, especially in the global market, because a particular name for a product will be genericized and the value of the product will decrease [46].

Meanwhile, from the craftsmen's point of view, GI and other IP protections are not considered as their priority [47]. They want more financial support to help them develop their industries, and hope that GI will aid their 'rural development'. Even after the GI registration, they are supposed to have more educational support to raise their awareness about IP systems, otherwise activation of GI may not go well [40].

The Indonesian government should consider the potential of craft products for GI first [39], and then they should provide proper basic education for the craftsmen and also 
promote the GI sign for the domestic and global market. This is to prevent the failure in the economic and social aspects, after the product has been registered for GI [35]. Lesser-known craft are more likely to face failure in the market due to low demand.

\section{Study Case: Jepara Carving Furniture}

Jepara carving furniture is one of the top export commodities in furniture sector. In 2008, the export value reached US \$108 million with some new destinations countries, such as the UEA and Egypt, as well as the main markets in the US and Europe. The industry employs around 64,000 people in Jepara, the north part of Java Island, and consists of 348 big companies, 36 companies owned by foreigners, and hundreds of small enterprises [48].

Before GI was applied in 2004, there was a dispute between two foreign companies selling Jepara carving furniture. A foreign company had registered their product catalogue containing 456 pictures of Jepara carving furniture, and then sued one local company and one foreign company for stealing their furniture designs in the catalogue. However, the copyright law was meant to protect the catalogue, not the designs in the catalogue. In the copyright law, it was mentioned that the owner of all 'prehistoric, historical, and other national cultural objects' is the state. Jepara carving designs belong to the public domain, because it is based on Jepara's community heritage [49].

This case illustrates that Jepara carving should be protected. The Jepara community was in danger if they were not allowed to produce something that was originally part of their culture because of the monopoly effect of unfair IP rights. Therefore, after the beginning of GI implementation in Indonesia, Jepara carving furniture was officially registered on 28 April 2010 as the third GI in the country [4]. Unfortunately, until 2012, based on Gabor's study [47], there was no significant effect of GI for Jepara carving industries. It was also discovered that the main problem was with the application system. Many traditional Jepara carving small enterprises did not care much about their legal company's status, so they were not able to register their company to join the GI sign. Besides, they had high confidence about their product and did not realize the importance of GI.

\section{Study Case: Sikka Ikat (Handmade Woven Fabric)}

Ikat is the fabric involving traditional technique with manual handwork, without machine. Sikka is the name of a region in East Nusa Tenggara province. Sikka ikat is one of the highly potential craft to be registered as GI because of its link with the terroir and unique characteristics [39]. In October 2015, Sikka ikat was in ongoing process to be officially registered as the second GI craft after Jeara carving furniture, since the Book of Requirement is under revision [50].

Based on the research done by [39], Sikka ikat has some advantages, such as the usage of local cottons with natural dyes from local plants, and their unique motifs. Registering Sikka ikat for GI will not only bring prosperity and create more financial benefit, but will also create positive impact in the social sector. In 2010, there were 6,297 people (most of them women) involved in Sikka ikat production. It is those workers who will reap the benefits of GI sign implementation. The sign will help consumers, especially foreigners and tourists, who cannot distinguish 'traditional' (with natural dyes and materials) from 'less traditional' (with chemical dyes) ikat. GI will also help to maintain the traditional style and motifs, as many craftsmen are not willing to make a new designs, even though collaboration with fashion designers has become more common.

\section{THE IMPORTANCE OF GI FOR INDONESIAN CRAFT}

\section{A. The Value of Crafts}

With more than 17,000 islands, Indonesia is rich with natural resources and various ethnicities. The combination of geographical location and biodiversity produces numerous traditional heritages, including 'know-hows' for craft [39]. Therefore, every region has their craft specialty that can be different from other ethnicities' [26]. For example, Bali is popular with the silver craft, while Lombok, the island next to Bali, is known for pearl jewelry craft.

The craft sector was growing 4.61 percent every year, since 2009-2013. There were five main export destination countries including the US, Japan, the UK, Germany, and Hong Kong. In 2013, the total value for export was USD $\$ 669.16$ million [51]. In addition, most of the craft industries are located in the countryside with the percentage of 80 percent and the rest is in the cities [10].

The consumption of craft is related to the 'cultural consumption capital' [52], due to the exoticness of craft products as 'cultural representation' [53]. During the globalization era, everyone can access the information about global goods and the demand for 'world' product is increasing in the worldwide market. The domestic market is also growing, with the increasing number of middle class society within the population of 250 million people in Indonesia [39]. Not only for domestic consumption, craft has also become an icon for tourism as souvenirs and gifts [53]. Even though GI products are still struggling to reach the niche in domestic level, with broader market, those products are believed to be more competitive as well and will bring benefits to the craftsmen [39]. For instance, Sikka ikat is also known as the specialty craft of East Nusa Tenggara and its current target market are not only fabric-enthusiast people, but also tourists.

\section{B. GI and Collaboration with Craft Industry}

The next step after GI registration is how to survive in the vast global market. Durand [40] stated that many entities in Indonesia are not aware of the activation of GI. They think about GI as a final goal, but actually GI is a tool to enhance a product's position in the market. Meanwhile, the craftsmen and people in this industry tend to respond to the cheap market's demand. As a result they lack creativity and innovation. This is an issue that needs to be addressed [54], [55]. Innovation can be created through collaboration, especially from two different actors [56]. Even though Calboli [46] believes that GI does not boost the incentive for innovation, the outcome can be 'stimulating competition and innovation', and 'stifle commercial innovation' [57]. With 
high-diversities and various characteristics of craft in Indonesia, there is a great opportunity to collaborate with other organizations, such as designers, big companies, or governments.

There are several benefits in implementing GI for craft industries. The author claims that these benefits also has the potential to encourage collaboration, not only in the creating process of craft products, but also in the broader context, such as the marketing, financial support and rural sustainability.

First, GI has a distinctive mark for each registered product. Between the producers and customers, the 'asymmetrical information' can be reduced by presenting the GI sign on the craft product or the packaging because it helps the customers to recognize the quality of the craft products [46]. Since GI is also like a shared trade mark, the branding system works in a collective way [40]. This means that a budget for marketing can be reduced as long as the producers maintain their quality. This will tackle the problem of cheap version or counterfeit product from other countries [58].

Second, craft with GI signs will have higher prices or even be considered as premium products. These products could create a new niche market [46]. Even though the analysis for further effect has not yet been done Kintamani Bali Arabica Coffee (unfortunately not a craft product, and only some producers signed for GI certification) has proved this. The producers maintained their quality, and as a result of its increased price, that coffee has become one of the most luxurious coffees in Indonesia [26]. In the craft industry, the craftsmen will have more profits than if they sold craft without GI certification. In addition, creating a new premium craft product can attract cafes, hotels, shopping malls or lavish tourist spots to create a collaboration for special exhibition or custom order decorations.

Third, GI is believed to help the development of rural areas [36], [40], in terms of environment and social aspects [14]. Many craft industries are based in rural areas [10] and they have to take care their geographical surroundings [46]. If natural materials are used, resource sustainability will be a concern. Those who make the craft must also ensure that their waste will not harm the environment in the long run. These responsibilities will be easier when they collaborate with the entire community, for instance waste management. GI registered craft are also expected to perform better in the market, so the industry can employ more people and prevent urbanization. In this case, government and banks can help to support by giving financial capital directly to the craft industries, because the small craft industries need them to grow their business.

Fourth, in this global trade era, GI registered craft are seen as a special product with unique characteristic [53] and as an advertising instrument [26]. This can be a unique selling point when the craft's element are incorporated into new innovation designs by collaborating with aspiring designers. Zulaikha [55] stated in her research in Indonesia that the collaboration of designers and craftsmen with participatory methods will create a positive result in the market. She explained that in participatory methods, the designers have a role as the craftsmen's 'partners, provocateurs, assistants, mediators and evaluators'. This method will cause benefits for everyone involved. The designers can appreciate the craftsmanship more while the craftsmen can be more innovative and aware of their potential. For instance, there may be a possibility the Jepara carving furniture will be displayed in an IKEA catalogue, or more international designers will introduce Sikka ikat in their collections.

Although the benefits are reasonable, there are some doubts concerning the GI effect. First, the current IP and GI system are not enough to safeguard the traditional cultural heritage, because the original objective of these systems are about economic benefits [46]. Second, the increasing demand for GI craft products can also create exploitation, not only for the environment, but also for the craftsmen [46]. Natural resources can be scarcer when many industries are competing to possess them and they are not responsible for the waste management. Craftsmen may be treated unfairly, such as overworking with less salary due the cost efficiency. Third, the market for GI products is not well established yet. Many customers are not accustomed with the GI sign [39], let alone the craftsmen who do not care much about the legal status [47].

All actors should work together to tackle these issues, especially the government who has a bigger part in envisioning craft to support the economy of the country. One recent government provision to enhance the collaboration between designers and craft industries is Designer Dispatch Service (DDS). DDS was initiated as a joint collaboration between the Ministry of Trade and the Japan International Cooperation Agency (JICA) started in 2012. Aiming for the export trade, the government selected several young designers to work together with local craft industries. The pilot project was run in 2012, and at that time only three rattan industries and two designers were involved [59]. Then, in 2014, DDS continued with 13 programs in 11 cities with different types of small industries [60]. Hopefully, there will be more collaboration projects in the future involving the craft industries with GI certification to help them innovate and survive the global market.

\section{CONCLUSION}

Over the last decades, there have been several attempts to control the world IP system for culture. Then, after TRIPS created the basic minimum protection for GI, many countries tried to monetize their cultural products based on GI Meanwhile, as a member of the TRIPS agreement, Indonesia set the GI regulation officially in 2001 [3] to boost the profit from the creative sector, including craft.

Indonesian craft as a cultural product now has a bigger opportunity to survive in the global market since GI system was implemented. Rooted with multi-ethnicity cultures and high biodiversity, this opportunity becomes bigger, especially with the current government discussion to launch a new GI law [15]. The current GI regulation and execution still have many flaws [3] and are not yet creating the expected advantages. This is important for Indonesian craft industries because it can benefits Indonesian people as the owners of the culture and actors of collaboration.

After a product gets a GI certification, it was found that the activation part of GI is rather neglected [47]. Therefore the 
craft industries will need support from different organizations to help them gain the GI benefits. Then, the benefits of GI for craft will drive collaboration to produce innovation, such as to protect consumers and craft people, to promote the nation's craft in the wider market, to help develop rural areas and to foster collaboration between craft industries and other actors. Some collaboration projects had been conducted between the governments and craft industries, but it will be better if there are more organizations and people connected for different types of programs.

This study has signified the importance of implementing GI for Indonesian craft which can benefits the stakeholders and the professionals in Indonesian craft industries. The government as the regulator, is better to collaborate with different entities to create a better result [16]. Further study is recommended to explore the hindrance of implementing GI in Indonesia, and financial and social implication in the craft industries after the GI implementation.

\section{ACKNOWLEDGMENT}

F. H. Arief thanks Dr. Nicola Searle from Institute for Creative and Cultural Entrepreneurship at Goldsmiths, University of London for the introduction to Geographical Indication issue and the encouragement to write this study.

\section{REFERENCES}

[1] V. King, "Anthropology and tourism in Southeast Asia," in Tourism in Southeast Asia, M. Hitchcock, V. T. King, M. Parnwell, Ed. Copenhagen: Nias Press, 2009, ch. 2, pp. 43-68.

[2] N. Natahadibrata T. J. Post, and J. B. Fri. Kadin to support creative economy agency. [Online]. Available: http://www.thejakartapost.com/news/2015/02/06/kadin-support-creati ve-economy-agency.html

[3] W. Sasongko, "The legal protection of geographical indications in Indonesia towards the ASEAN economic community," presented at the First International Conference on Law, Business and Government 2013 Bandar Lampung Univeristy, Bandar Lampung.

[4] DJKI. Indikasi Geografis Terdaftar. [Online]. Available: http://119.252.174.21/indikasi-geografis/

[5] D. Mitchell, "There's no such thing as culture: Towards a reconceptualization of the idea of culture in geography," Transactions of the Institute of British Geographers, vol. 20, no. 1, 1995, pp. 102-116, Web.

[6] C. Kramsch, Language and Culture, Oxford University Press, Oxford. 1998.

[7] L. Arizpe. Culture and science. [Online]. Available: http://www.pas.va/content/dam/accademia/pdf/sv105/sv105-arizpe.pd $\mathrm{f}$

[8] T. H. Erikson, "Between universalism and relativism: A critique of the UNESCO concepts of culture," Culture and Rights: Anthropological Perspectives, Cambridge University Press.

[9] P. Greenhalgh, "The history of craft," The Culture of Craft, Manchester University Press, Manchester, 1997. pp. 20-52.

[10] E. Zulaikha and M. Brereton, "Innovation strategies for developing the traditional souvenir craft industry," presented at the First International Postgraduate Conference on Engineering, Designing and Developing the Built Environment for Sustainable Wellbeing, Queensland University of Technology, Queensland, 2011, pp. 53-58

[11] B. Metcalf, "Craft and art, culture and biology," The Culture of Craft, Manchester University Press, Manchester, 1997.

[12] D. S. Gangjee, "Geographical indications protection for handicrafts under TRIPS," M.Phil Thesis, University of Oxford, Oxford, 2002.

[13] WIPO. Intellectual property and traditional cultural expressions/folklore. (2005). [Online]. Available: http://www.wipo.int/edocs/pubdocs/en/tk/913/wipo_pub_913.pdf

[14] WIPO. Geographical indication: An introduction. (2003). [Online]. Available:

http://www.wipo.int/edocs/pubdocs/en/geographical/952/wipo_pub_9 52.pdf
[15] DJKI. Seminar 'geographical indications: International scenario and EU agreements with trade partners. [Online]. Available: http://humas.dgip.go.id/seminar-geographical-indocations-internation al-scenario-and-eu-agreements-with-trade-partners/

[16] D. Tapscott and A. D. William, Wikinomics: How Mass Collaboration Changes Everything, Extended edition, Atlantic Books, London, 2008.

[17] S. H. Poggenpohl, "Practicing collaborative action in design," in Design Integration, Intellect Books, S.H. Poggenpohl, K. Sato, (Eds.), pp. 137-162. 2009.

[18] S. Doorley and S. Witthoft, Make Space, John Wiley \& Sons Inc, 2012.

[19] N. Mezey, "The paradoxes of cultural property," Columbia Law Rev, vol. 107, pp. 2004-2046. 2007.

[20] L. Hyde, Common as Air, Farrar, Straus and Giroux, New York, 2010.

[21] J. Locke, Two Treatises on Government, Student edition, Cambridge University Press, Cambridge, 1960.

[22] Foucault. Foucault, 'Author function. [Online]. Available: http://faculty.georgetown.edu/irvinem/theory/Foucault-AuthorFunctio n.html

[23] J. Howkins, The Creative Economy, The Penguin Group, London. 2002.

[24] E. C. Hettinger, "Justifying intellectual property," Philos. Public Aff, vol. 18,1989 , pp. 31-52

[25] C. Lury, Cultural Rights: Technology, Legality and Personality, Routledge, London, 1993.

[26] S. Mawardi, "Establishment of geographical indication protection system in Indonesia, case in coffee," presented at Worldwide Symposium on Geographical Indications. WIPO and the Patent Office of the Republic of Bulgaria, 2009.

[27] A. Taubman. Indigenous innovation: New dialogues, new pathways. Indigenous Peoples' Innovation: Intellectual Property Pathways to Development. [Online]. Available: http://press.anu.edu.au/apps/bookworm/view/Indigenous+Peoples'+In novation:+Intellectual+Property+Pathways+to+Development/9731/ch 06.html

[28] M. Sunder. The invention of traditional knowledge. Law Contemp Probl. [Online]. Available: http://www.jstor.org/stable/27592181

[29] S. Maulik. Skirting the issue: How international law fails to protect traditional cultural marks from IP Thef. Chic. J. Int. Law. [Online]. Available:

http://chicagounbound.uchicago.edu/cgi/viewcontent.cgi?article $=150$ $3 \&$ context $=$ cjil

[30] D. Gervais, "Traditional innovation and the ongoing debate on the protection of Geographical Indications," in Indigenous Peoples' Innovation: Intellectual Property Pathways to Development. P. Drahos, S. Frankel, (Eds.), ANU E Press, Canberra, 2012.

[31] D. Rangnekar. The Pros and Cons of Stronger Geographical Indication Protection. (2002). [Online]. Available: https://www.iprsonline.org/ictsd/docs/RangnekarBridgesYear6N3Mar chApril2002.pdf

[32] WTO. WTO|WTO Analytical Index: Guide to WTO Law and Practice - Agreement on Trade-Related Aspects of Intellectual Property Rights [Online]. Available: URL https://www.wto.org/english/res_e/booksp_e/analytic_index_e/trips_0 2_e.htm

[33] K. Raustiala and S. R. Munzer. The global struggle over geographic indications. Eur. J. Int. Law. [Online]. Available: http://www.ejil.org/pdfs/18/2/227.pdf

[34] I. Calboli. Expanding the Protection of Geographical Indications of Origin Under TRIPS: Old Debate or New Opportunity? [Online]. Available: http://ssrn.com/abstract=893193

[35] C. Bramley, E. Bienabe, and J. Kirsten. The Economics of Geographical Indications: Towards A Conceptual Framework for Geographical Indication Research in Developing Countries. [Online]. Available:

http://www.wipo.int/export/sites/www/ip-development/en/economics/ pdf/wo_1012_e_ch_4.pdf

[36] D. Zografos. Geographical indications and socio-economic development. [Online]. Available: http://papers.ssrn.com/sol3/papers.cfm?abstract_id=1628534

[37] M. Rahmah. The extension of geographical indication protection Necessary for developing country. Jurnal Mimbar Hukum Fakultas Hukum Universitas Gadjah Mada. [Online]. Available: http://mimbar.hukum.ugm.ac.id/index.php/jmh/article/view/504/344

[38] B. Parry, "Geographical indications: Not all "champagne and roses," Trade Marks and Brands, L. Cambridge University Press, 2011, pp. 361-380.

[39] S. Fournier, S. Mawardi, and S. Septiono. Objective 7: Study on Potential of GIs and Selection of 4 Specific Products for Support, 
Indonesian - Swiss Intellectual Property (ISIP) Project. [Online]. Available:

https://www.ige.ch/fileadmin/user_upload/Juristische_Infos/e/report_ of_the_first_mission-oct-2012.pdf

[40] C. Durand, S. Fournier, and E. Thevenod-Mottet. Effects of geographical indication registration and activation, thoughts on the indonesian situation. [Online]. Available: https://www.researchgate.net/profile/Claire_Durand/publication/2607 19671_Effects_of_geographical_indication_registration_and_activati on._Thoughts_on_the_Indonesian_situation/links/00b7d53217882a15 77000000.pdf

[41] R. Pant. Protecting and promoting traditional knowledge in India [Online]. Available: http://pubs.iied.org/pdfs/16576IIED.pdf

[42] A. Mevhibe and M. Ozdemir. The role of geographical indication in brand making of Turkish handcrafts. Indian J. Tradit. Knowl. [Online]. Available:

http://nopr.niscair.res.in/bitstream/123456789/14382/1/IJTK\%2011(3 \%20420-426.pdf

[43] P. Tanasanti, Geographical Indications - Where Do We Stand Today? [Online].

Available: http://www.wipo.int/edocs/mdocs/geoind/en/wipo_geo_bkk_13/wipo _geo_bkk_13_5.pdf

[44] B. O’Connor, Sui Generis Protection of Geographical Indications. [Online].

Available: http://students.law.drake.edu/aglawjournal/docs/agVol09No3-OConn or.pdf

[45] R. J. Coombe, S. Ives, and D. Huizenga, "Geographical indications: The promise, perils and politics of protecting place-based products,' The Sage Handbook of Intellectual Property, Sage Publications, London, 2014, pp. 207-223.

[46] I. Calboli. Of markets, culture, and terroir: The unique economic and culture-related benefits of geographical indications of origin International Intellectual Property: A Handbook of Contemporary Research, Research Handbooks in Intellectual Property. [Online]. Available:

http://papers.ssrn.com/sol3/papers.cfm?abstract_id=2329566

[47] M. M. Gabor. Efektivitas Perlindungan Hukum Indikasi Geogarafis di Indonesia. [Online]. Available: http://lib.ui.ac.id/file?file=digital/20302058-T30322-Efektivitas\%20p erlindungan.pdf

[48] The Jakarta Post. Jepara administration patents 99 wood carving motifs [Online] Available:

$\mathrm{L}$ http://www.thejakartapost.com/news/2009/06/15/jepara-administratio n-patents-99-wood-carving-motifs.html

[49] I. P. Managing. Indonesia: Loopholes in copyright law. [Online]. Available: http://www.managingip.com/Article/3084158/Indonesia-Loopholes-in -copyright-law.html
[50] WTO. Technical Cooperation Activities: Information From Members. [Online]. Available: https://docs.wto.org/dol2fe/Pages/FE_Search/.../q/IP/C/W610A3.pdf

[51] Ministry of Trade. World craft council (WCC) award of excellence for handicraft 2014. [Online]. Available: http://www.kemendag.go.id/en/events/2014/04/22/world-craft-council -wcc-award-of-excellence-for-handicraft-2014

[52] R. E. Caves, Creative Industries, Harvard University Press, 2002.

[53] G. Hickney, "Craft within a consuming society," The Culture of Craft, in: P. Dormer, (Ed.), Manchester University Press, Manchester. 1997.

[54] Livingetc. Designer dispatch service. [Online]. Available: http://www.livingetcindonesia.com/read-news-10-0-174-designer-disp atch-service.livingetc-indonesia

[55] E. Zulaikha. Collaborative learning in the rural Indonesian craft industry. [Online]. Available: http://eprints.qut.edu.au/79247/1/Ellya_Zulaikha_Thesis.pdf

[56] The Guardian. Leadership paradox: why collaboration is key to innovation. [Online]. Available: URL http://www.theguardian.com/sustainable-business/leadership-paradoxcollaboration-key-to-innovation

[57] D. Giovannucci, T. Josling, W. Kerr, B. O’Connor, M. T. Yeung Guide to geographical indications: Linking products and their origins. [Online]. Available: http://mpra.ub.uni-muenchen.de/27955/

[58] B. J. Fowler, "Preventing counterfeit craft design," Poor People's Knowledge: Promoting Intellectual Property in Developing Countries, J.M. Finger, P. Schuler, (Eds.), World Bank Publication, Washington, pp. 113-132, 2004.

[59] Ministry of trade. Directorate general for national export development. [Online].

Available: http://djpen.kemendag.go.id/app_frontend/accepted_rsses/view/51f0c 198-ba60-49cc-804b-5a620a1e1e48

[60] Republika. Genjot Ekspor, Kemendag Fokus Tingkatkan Desain Produk UKM. [Online]. Available: http://www.republika.co.id/berita/ekonomi/makro/14/11/27/nfpbuc-ge njot-ekspor-kemendag-fokus-tingkatkan-desain-produk-ukm

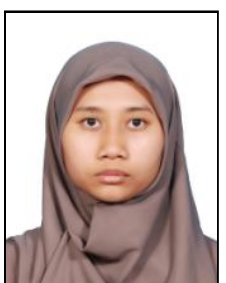

Fadilah H. Arief was born in Cirebon, Indonesia in 1991. Fadilah earned her BA in product design from Institut Teknologi Bandung, Indonesia in 2014, and she is now studying at Goldsmiths, University of London, with the MA creative and cultura entrepreneurship programme. Her research interests are crafts, design, creative marketing, and tourism destination. 